\title{
Ovarian follicle development in the laying hen is accompanied by divergent changes in inhibin $A$, inhibin $B$, activin $A$ and follistatin production in granulosa and theca layers
}

\author{
T M Lovell, R T Gladwell, N P Groome ${ }^{\mathbf{1}}$ and P G Knight \\ School of Animal and Microbial Sciences, University of Reading, Whiteknights, Reading RG6 6AJ, UK \\ ${ }^{1}$ School of Biological and Molecular Sciences, Oxford Brookes University, Oxford OX3 OBP, UK \\ (Requests for offprints should be addressed to P G Knight; Email: p.g.knight@reading.ac.uk)
}

\begin{abstract}
To study the potential involvement of inhibin A (inhA), inhibin B (inhB), activin A (actA) and follistatin (FS) in the recruitment of follicles into the preovulatory hierarchy, growing follicles (ranging from $1 \mathrm{~mm}$ to the largest designated F1) and the three most recent postovulatory follicles (POFs) were recovered from laying hens $(n=11)$. With the exception of $<4 \mathrm{~mm}$ follicles and POFs, follicle walls were dissected into separate granulosa $(G)$ and theca $(T)$ layers before extraction. Contents of inhA, inhB, actA and FS in tissue extracts were assayed using specific two-site ELISAs and results are expressed per mg DNA. InhB content of both $\mathrm{G}$ and $\mathrm{T}$ followed a similar developmental pattern, although the content was $>4$-fold higher in $G$ than in $\mathrm{T}$ at all stages. InhB content was very low in follicles $<4 \mathrm{~mm}$ but increased $\sim 50$-fold $(P<0 \cdot 0001)$ to peak in $7-9 \mathrm{~mm}$ follicles, before falling steadily as follicles entered and moved up the follicular hierarchy (40-fold; $8 \mathrm{~mm}$ vs F2). In stark contrast, inhA remained very low in prehierarchical follicles $(\leq 9 \mathrm{~mm})$ but then increased progressively as follicles moved up the preovulatory hierarchy to peak in F1 ( 100-fold increase; $P<0 \cdot 0001)$; In F1 $>97 \%$ of inhA was confined to the $G$ layer whereas in 5-9 $\mathrm{mm}$ follicles inhA was only detected in the $\mathrm{T}$ layer.
\end{abstract}

Both inhA and inhB contents of POFs were significantly reduced compared with F1. Follicular actA was mainly confined to the $\mathrm{T}$ layer although detectable levels were present in $\mathrm{G}$ from $9 \mathrm{~mm}$; actA was low between 1 and $9 \mathrm{~mm}$ but increased sharply as follicles entered the preovulatory hierarchy ( $\sim 6$-fold higher in F4; $P<0 \cdot 0001$ ); levels then fell $\sim 2$-fold as the follicle progressed to F1. Like actA, FS predominated in the $T$ although significant amounts were also present in the $G$ of prehierarchical follicles $(4-9 \mathrm{~mm})$, in contrast to actA, which was absent from the G. The FS content of T rose $\sim 3$-fold from $6 \mathrm{~mm}$ to a plateau which was sustained until F1. In contrast, the FS content of $\mathrm{G}$ was greatest in prehierarchical follicles and fell 4-fold in F4-F1 follicles. ActA and FS contents of POFs were reduced compared with F1. In vitro studies on follicle wall explants confirmed the striking divergence in the secretion of inhA and inhB during follicle development. These findings of marked stage-dependent differences in the expression of inhA, inhB, actA and FS proteins imply a significant functional role for these peptides in the recruitment and ordered progression of follicles within the avian ovary.

Journal of Endocrinology (2003) 177, 45-55

\section{Introduction}

The domestic fowl provides a unique model for the study of the mechanisms involved in follicular development. The single left ovary contains follicles of various sizes and developmental stages including quiescent primordial follicles, prehierarchical growing follicles and large yolk-filled follicles that have been recruited to the well-ordered preovulatory hierarchy. Growth from 3 to $5 \mathrm{~mm}$ takes 3 days, from 5 to $8 \mathrm{~mm} 2$ days and from $8 \mathrm{~mm}$ to ovulation $(\sim 40 \mathrm{~mm}) 6$ days (Gilbert et al. 1983), with the total time for development from $1.5 \mathrm{~mm}$ to $40 \mathrm{~mm}$ being around 17 days (Perry et al. 1983). As follicles increase in size there is a progressive decrease in the number of follicles in that size class, with the ovary of the laying hen containing $\sim 50$ follicles between 1 and $8 \mathrm{~mm}$ in diameter. The decrease in follicular number is brought about by apoptosis (for review see Tilly 1996) and extensive inter-nucleosomal DNA cleavage has been identified within both granulosa $(G)$ and thecal (T) layers of atretic regressing follicles (Tilly et al. 1991c). Characteristically, once follicles grow beyond $\sim 9 \mathrm{~mm}$ in diameter they are committed to the rapidly growing preovulatory hierarchy (typically the largest five to ten follicles) and the incidence of atresia is very low (Gilbert et al. 1983). The largest follicle $(\sim 40 \mathrm{~mm})$, designated $\mathrm{F} 1$, will ovulate next; upon doing so the second 
largest follicle (F2) is promoted to this position and will ovulate some $24-26 \mathrm{~h}$ later providing the end of an ovulatory 'sequence' has not been reached.

Two forms of inhibin $(A(\alpha-\beta A)$ and $B(\alpha-\beta B))$ and three forms of activin $(A(\beta A-\beta A), A B(\beta A-\beta B)$ and $B$ $(\beta B-\beta B))$ are present in the ovaries of most mammalian species examined (Knight \& Glister 2001). mRNAs encoding inhibin/activin $\alpha-, \beta \mathrm{A}$ - and $\beta \mathrm{B}$-subunits are also detectable in chicken ovarian follicles (Chen \& Johnson 1996, Davis \& Johnson 1998) and increasing evidence suggests inhibin-related proteins have important roles in regulating ovarian function in birds. Inhibin $A$ (inhA) and activin $A(a c t A)$ proteins have been identified in the $G$ and $\mathrm{T}$ layers of chicken preovulatory follicles (Lovell et al. 1998, 2001) and plasma inhA follows a cyclic pattern during the hen ovulatory cycle (Lovell et al. 2000b). Primary cell cultures of $\mathrm{G}$ cells from preovulatory (F1, F2 and F3) follicles secrete inhA in vitro in a luteinizing hormone ( $\mathrm{LH}) /$ follicle-stimulating hormone (FSH)responsive manner; secretion of inhA is also modulated by insulin-like growth hormone-I (IGF-I) and actA (Lovell et al. 2002a,b). However, these authors were unable to detect secretion of inhibin $B$ (inhB) by hen $G$ cells from F1-F3 follicles. While there is no information on the production of inhB, activin $\mathrm{AB}$, activin $\mathrm{B}$ or follistatin (FS) proteins by the chicken ovary, mRNAs for both $\beta \mathrm{B}$ subunit and FS are expressed in the chicken ovary with maximal expression in the $G$ layer of early hierarchical follicles (F6-F8) and small yellow follicles (Davis \& Johnson 1998).

Given the paucity of information on the expression of inhibin-related proteins in the avian ovary, particularly in prehierarchical follicles, in this study we have used a panel of specific two-site enzyme-linked immunosorbent assays (ELISAs) to quantify inhA, inhB, actA and FS contents in both $G$ and $T$ layers and thus investigate the potential involvement of these proteins during follicular development and, in particular, in the recruitment of growing follicles to the preovulatory hierarchy. We have also compared the in vitro secretory capacity (in terms of both steroids and inhibin-related peptides) of follicle wall explants from a range of follicle sizes ( $4 \mathrm{~mm}$ to $\mathrm{F} 1$ status).

\section{Materials and Methods}

\section{Experimental animals}

Laying hens (ISA Brown) towards the end of their first year of lay were caged individually and maintained under a standard long-day photo-schedule of $16 \mathrm{~h}$ of light and $8 \mathrm{~h}$ of darkness, at an ambient temperature of $21-23^{\circ} \mathrm{C}$. Food and water were freely available. Ovipositions were recorded using time-lapse recording technology and used to predict the time of ovulation.

\section{Recovery and preparation of follicular tissue extracts}

Hens $(n=11)$ were killed by cervical dislocation $14-18 \mathrm{~h}$ after predicted ovulation of a midsequence egg. Ovarian follicles of $1 \mathrm{~mm}$ in diameter and above, and the three most recent postovulatory follicles (POF) were dissected from the ovary and their diameters recorded. Follicles above $4 \mathrm{~mm}$ in diameter were dissected into separate $\mathrm{G}$ and T layers (Gilbert et al. 1977) which were washed in saline $(0 \cdot 75 \%(\mathrm{w} / \mathrm{v}))$, snap frozen in solid $\mathrm{CO}_{2}$ and stored at $-70{ }^{\circ} \mathrm{C}$. Follicles smaller than $4 \mathrm{~mm}$ and POFs were snap frozen without further dissection. Each individual tissue specimen was subsequently homogenized (apart from $1-1.9 \mathrm{~mm}$ and $2-3.9 \mathrm{~mm}$ follicles which were homogenized as two follicle pools) in a known volume of buffer A (phosphate-buffered saline (PBS) containing 1\% $(\mathrm{w} / \mathrm{v})$ bovine serum albumin (BSA) and $0.1 \%(\mathrm{w} / \mathrm{v})$ sodium azide) using an Ultra-Turrax T8 homogenizer (IKA, Staufen, Germany) to give the following volume/ mass ratio homogenates: $3: 1$ ratio for $\geq 9 \mathrm{~mm}$ diameter follicle $\mathrm{T}$ tissue, $\mathrm{POF}$ tissue and $1-1.9 \mathrm{~mm}$ and $2-3.9 \mathrm{~mm}$ follicle tissue pools; 9:1 ratio for 4-8.9 mm diameter follicle $\mathrm{T}$ tissue and all $\mathrm{G}$ tissue samples. A $3 \mu \mathrm{l}$ aliquot of homogenate was removed for DNA estimation using a fluorometric assay (Labarca \& Paigen 1980) before centrifugation $(3500 \mathrm{~g}$ for $15 \mathrm{~min})$. Extract supernatants were stored at $-70{ }^{\circ} \mathrm{C}$ until assayed for inhA, inhB, actA and FS; results are expressed on a per mg DNA basis.

\section{Follicle wall explant culture}

Hens $(n=5)$ were killed by cervical dislocation approximately $10 \mathrm{~h}$ after ovulation of a midsequence egg. The largest preovulatory follicle (F1) and 4-10 mm diameter prehierarchical follicles were removed from each hen and immediately placed in sterile Hanks' balanced salt solution (Gibco-BRL, Uxbridge, Middx, UK). In a laminar flow cabinet, prehierarchical follicles were sorted into $4-5.9 \mathrm{~mm}$ $(n=9), 6-7.9 \mathrm{~mm}(n=6)$ and $8-9.9 \mathrm{~mm}(n=4)$ diameter bands. Randomly selected follicles from each band were cut into equal halves and rinsed in sterile saline to remove adhering yolk. F1 preovulatory follicles $(n=5)$ were cut down the stigma with a sterile scalpel blade and yolk was allowed to pour out into a Petri dish. The follicle was then cut into $1 \mathrm{~cm}^{2}$ pieces taking care to make sure that the $\mathrm{G}$ and $\mathrm{T}$ layers remained together. Individual follicles (two halves or one piece of F1) were placed into a single well of a 24-well plate (Falcon 3047; Becton Dickinson Labware, Franklin Lakes, NJ, USA) containing $1 \mathrm{ml}$ culture media (Medium 199 with $25 \mathrm{mM}$ Hepes, 0·1\% (w/v) BSA (fraction $\mathrm{V}$ ), $2 \mathrm{mM}$ L-glutamine, $5 \mu \mathrm{g} / \mathrm{ml}$ apotransferrin, $5 \mathrm{ng} / \mathrm{ml}$ sodium selenite and $1 \%(\mathrm{v} / \mathrm{v})$ antibiotic/ antimycotic solution; all from Sigma UK Ltd, Poole, Dorset, UK). At the termination of culture, the conditioned media were removed and stored at $-20{ }^{\circ} \mathrm{C}$ until assayed for inhA, inhB, actA, FS, androstenedione (A4), 
progesterone (P4) and oestradiol (E2). Tissues (combined $G$ and $T$ layers) were removed, weighed and homogenized in a known volume of buffer $A$ to give a 20:1 volume:mass ratio homogenate. A $3 \mu \mathrm{l}$ aliquot was then removed for DNA estimation (Labarca \& Paigen 1980), allowing hormone secretion to be expressed on a per $\mu \mathrm{g}$ DNA basis, thereby normalizing for cell numbers.

\section{Tissue samples for FS assay validation}

Follicles of 6-8 $\mathrm{mm}$ diameter were obtained from laying hens $(n=2)$ and prepared as described above. A testicular extract was also prepared as a source of FS. Portions of cockerel testis (from 12 birds; collected at 24 weeks of age and snap frozen in dry ice) were weighed, homogenized in buffer A to give a 1:1 volume/mass homogenate, centrifuged ( $3500 \mathrm{~g}$ for $15 \mathrm{~min}$ ) and the supernatants were pooled and stored at $-20{ }^{\circ} \mathrm{C}$ until required.

\section{Immunoassays}

InhA, inhB and actA were determined using two-site ELISAs that employ monoclonal antibodies (mAbs) raised against synthetic peptide fragments of the human $\alpha_{-}, \beta$ Aand $\beta$ B-subunits (Muttukrishna et al. 1994, Groome et al. 1996, Knight et al. 1996). Each of these assays was validated for use in the chicken as described previously (Lovell et al. 1998, 2000a, 2001). Recombinant human (rh) inhA, actA (NIBSC, Potters Bar, Herts, UK) and inhB (a gift from Dr T Woodruff, NorthWestern University, Evanston, IL, USA) were used as assay standards and detection limits were 2, 50 and $15 \mathrm{pg} / \mathrm{ml}$ respectively. Within- and between-plate coefficients of variation $(\mathrm{CV})$ were $<10 \%$ for each assay. Concentrations of P4 (Sauer et al. 1986), A4 (Wrathall \& Knight 1995) and E2 (Glister et al. 2001) were determined by competitive immunoassay as previously described. Within- and between-assay CV values for steroid assays were all $<10 \%$.

The FS ELISA employs a pair of mAbs raised in one of our laboratories (N P G) against rh FS-288 (capture antibody: $\mathrm{mAb} 1 / 1$; detector antibody: biotinylated $\mathrm{mAb}$ 17/2; Evans 1997). All steps of the assay were carried out at room temperature. In brief, $\mathrm{mAb}$-coated ELISA plates (Nunc-maxisorb immunoplate F96; Scientific Laboratory Supplies Ltd, Nottingham, Notts, UK) were prepared in advance by overnight incubation with mAb $1 / 1(10 \mu \mathrm{g} /$ $\mathrm{ml}$ ) in $50 \mu \mathrm{l} 0 \cdot 1 \mathrm{~mol} / 1$ sodium bicarbonate solution. Plates were washed three times with wash buffer (Tris-buffered saline (TBS) containing $0 \cdot 1 \%(\mathrm{v} / \mathrm{v})$ Tween-20 and $0 \cdot 1 \%$ (w/v) sodium azide; $\mathrm{pH} 7 \cdot 2$ ) before adding $250 \mu \mathrm{l} \mathrm{FS}$ assay diluent (PBS containing $5 \%(\mathrm{w} / \mathrm{v})$ BSA and $0 \cdot 1 \%(\mathrm{w} / \mathrm{v})$ sodium azide; $\mathrm{pH} 7 \cdot 2$ ) to each well and sealing plates for storage at $4{ }^{\circ} \mathrm{C}$. Standards $(0 \cdot 31-20 \mathrm{ng}$ rh FS-288/ml; NHPP, Torrance, CA, USA) and samples were diluted in FS assay diluent. Duplicate $100 \mu$ aliquots of standard/ sample were added to $\mathrm{mAb}$-coated wells and the plate was

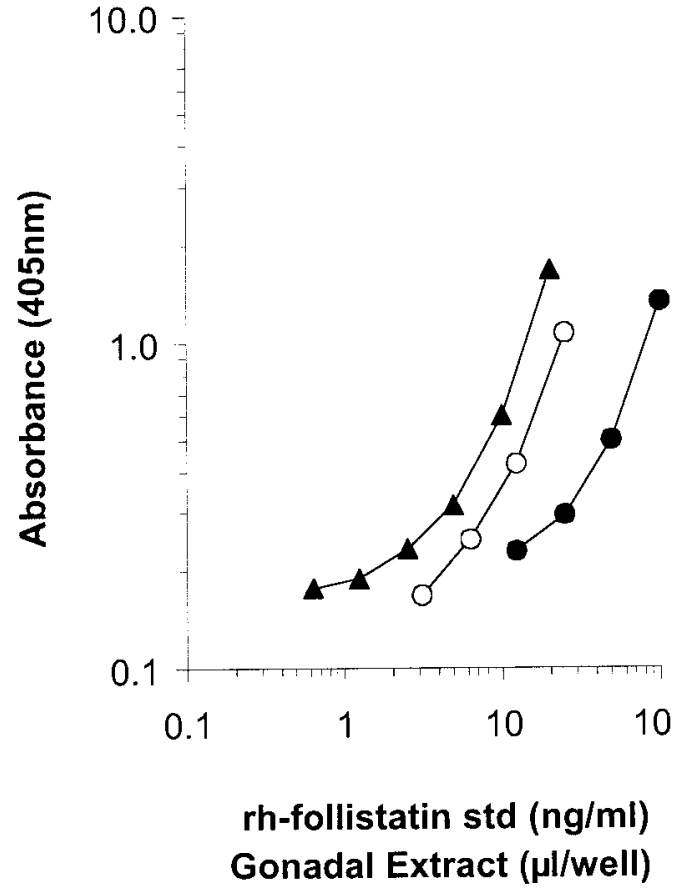

Figure 1 Representative dose-response curves in the two-site ELISA for FS, showing parallelism between the rh FS-288 standard preparation $(\mathbf{\Delta})$ and serial dilutions of extract of pooled T cells from 6-8 $\mathrm{mm}$ diameter chicken follicles $(\bigcirc)$ and adult cockerel testis $(-)$. Values are the means of duplicate determinations.

incubated overnight in a sealed moist box. The following day, the plate was washed ten times and $50 \mu \mathrm{l}$ TBS containing $1 \mu \mathrm{g}$ biotinylated $\mathrm{mAb}$ 17/2 was added. After $4 \mathrm{~h}$ in a moist box the plate was washed ten times and $50 \mu \mathrm{l}$ streptavidin alkaline phosphate conjugate (Sigma) was added (1:10 000 dilution in TBS) and after a further $2 \mathrm{~h}$ incubation the plate was washed and banged to dryness on paper toweling. Bound alkaline phosphatase was detected using a commercial signal amplification kit (ELISA Amplification System; Life Technologies Ltd, Uxbridge, Middx, UK) used according to the manufacturer's instructions. Absorbances were read at $405 \mathrm{~nm}$ (reference wavelength $650 \mathrm{~nm}$ ) using an automated microplate reader (Emax; Molecular Devices Ltd, Wokingham, Berks, UK) and assay data was interpreted using RIACalc software (Amersham-Pharmacia Biotech UK Ltd, Amersham, Bucks, UK). As shown in Fig. 1 serial dilutions of pooled extracts of chicken $\mathrm{T}$ and testicular tissue gave response curves in the FS ELISA that were parallel to the rh FS-288 standard curve. Linear regression analysis gave a poor fit to the curvilinear log-log transformed dose-response curves and so statistical confirmation of parallelism was made by two-way ANOVA. The absence of a significant dose $\times$ preparation interaction indicated no significant departure from parallelism. The recovery of known amounts of exogenous FS standard added to pooled 
samples before assay was quantitative and addition of rh actA $(10-160 \mathrm{ng} / \mathrm{ml})$ to pooled samples before assay did not interfere with the absorbance response generated (data not shown). The detection limit of the assay was $0.6 \mathrm{ng} / \mathrm{ml}$ and mean within- and between-plate $\mathrm{CV}$ values determined using pooled testis extract (1:4 dilution) containing the equivalent of $5 \mathrm{ng}$ rh FS were both less than 10\%.

\section{Statistical analysis}

One-way ANOVA was used in conjunction with post-hoc Fisher's protected least significant difference (PLSD) test to determine whether hormone concentrations differed between follicle categories. Post-hoc tests were only performed when the ANOVA yielded a significant $F$ ratio. $P<0.05$ was considered to be significant. Unless otherwise stated, values are the means \pm S.E.M.

\section{Results}

\section{InhB and inh $A$ concentrations in $G$ and $T$ layers of ovarian follicles}

Tissue concentrations ( $\mathrm{ng} / \mathrm{mg}$ DNA) of inhB and inhA in extracts of whole follicles or separate $G$ and $T$ layers are shown in Fig. 2. InhB was measurable in all follicle size classes studied (1 mm-F1) and the inhB content of the G layer was between 2.5- and 10-fold higher than that of the corresponding $\mathrm{T}$ layer. Follicular inhB content rose dramatically $(\sim 40$-fold; $P<0 \cdot 0001)$ during prehierarchical follicular development, peaking in $8-9 \mathrm{~mm}$ follicles, before falling steeply ( $\sim 30$-fold; $P<0 \cdot 0001)$ as follicles entered and progressed through the preovulatory hierarchy to the F2/F1 position. InhB levels were $70-$ and 30 -fold higher respectively in $G$ and $T$ layers of $8-8.9 \mathrm{~mm}$ follicles compared with $\mathrm{G}$ and $\mathrm{T}$ layers of $2-3.9 \mathrm{~mm}$ follicles. The inhB rise in $G$ preceded that in $T$, with values in 4-4.9 $\mathrm{mm} \mathrm{G}$ tissue and 6-6.9 $\mathrm{mm} \mathrm{T}$ tissue being significantly higher than those in the preceding follicle size category. Follicular inhB fell after ovulation with the content in POFs $\sim 5$-fold less than in the preovulatory F1 follicle.

In complete contrast to inhB, follicular inhA content was very low in follicles between 1 and $9 \mathrm{~mm}$ in diameter but increased progressively as follicles entered and progressed up the preovulatory hierarchy $(\sim 100$-fold increase from $5-6 \mathrm{~mm}$ to $\mathrm{F} 1 ; P<0 \cdot 0001)$ with the steepest rise ( 20-fold) between F2 and F1. In the F1 follicle, over $97 \%$ of its inhA content was present in the G layer whereas in follicles on the point of entry to the preovulatory hierarchy ( 9 mm-F5) only $\sim 70 \%$ was present in the $G$ layer with $\sim 30 \%$ in the $T$ layer. In follicles ranging from 5 to $9 \mathrm{~mm}$, inhA was only detected in the T layer and in follicles $<5 \mathrm{~mm}$ inhA was undetectable. The inhA content of POFs was $<2 \%$ of that in F1.
Act $A$ and FS concentrations in $G$ and $T$ layers of ovarian follicles

Tissue concentrations of actA and FS in extracts of whole follicles or separate $G$ and $T$ layers are shown in Fig. 3. In contrast to inh A and B, actA levels were invariably much higher in the $\mathrm{T}$ than the corresponding $\mathrm{G}$ layer $(4 \mathrm{~mm}-\mathrm{F} 1$ follicles). While actA was measurable in all follicle classes studied $(1 \mathrm{~mm}-\mathrm{F} 1)$, it was below the assay detection limit in the $G$ layer of follicles $<9 \mathrm{~mm}$ and remained at uniformly low levels in the G layer of F5-F1 preovulatory follicles. $\mathrm{T}$ actA content remained relatively constant between 2 and $9 \mathrm{~mm}$ but increased sharply ( $\sim$-fold; $P<0 \cdot 001)$ in the $9 \mathrm{~mm}-\mathrm{F} 5$ follicle category and continued to rise until F4/F3. Levels then fell progressively through F2 to F1 and continued to fall after ovulation with POF 1, POF 2 and POF 3 containing approximately 55, 35 and $25 \%$ of that seen in $\mathrm{F} 1$.

Like actA, FS predominated in the $\mathrm{T}$ layer although significant levels were present in the $G$ layer of prehierarchical follicles (5-9 $\mathrm{mm}$ ), which, as mentioned above, were devoid of actA. T FS content increased sharply at 6-7 mm ( 3-fold; 5 vs $5-6 \mathrm{~mm} ; P<0 \cdot 01)$ and remained at this high level through to F1 status. FS was undetectable in the $G$ layer of $4-5 \mathrm{~mm}$ follicles but was detected in 5-6 $\mathrm{mm}$ follicles. After showing a small rise $(\sim 50 \%$ higher at $8-9 \mathrm{~mm} ; P<0 \cdot 05)$ FS content of the $G$ layer subsequently fell $(80 \%$ decrease; $8 \mathrm{~mm}$ vs $\mathrm{F} 4 ; P<0 \cdot 01)$ and remained at this relatively low level through to F1. Total FS levels in POFs were $\sim 5$-fold less than in F1.

Since FS is an actA-binding protein we subsequently calculated the ratio of actA to FS in combined $T$ and $G$ layers and plotted this against follicle size (Fig. 4). Follicular actA:FS ratio was relatively high in the smallest size category analysed $(1-2 \mathrm{~mm})$ but decreased ( $\sim$-fold; $P<0 \cdot 01)$ to a nadir in $7-9 \mathrm{~mm}$ follicles. Transition into the preovulatory hierarchy was associated with a marked increase in actA:FS ratio ( $>7$-fold; $P<0.001)$ which peaked in F4 follicles before falling slightly from F4 to F1 $(\sim 30 \% ; P<0 \cdot 05)$. After ovulation, actA:FS ratio increased $2 \cdot 5$-fold $(P<0 \cdot 01)$ to a value higher than at any other stage of follicle development.

\section{Hormone secretion from follicle wall explants in vitro}

Secretion of inhibin-related peptides (inhA, inhB, actA, FS) and steroids (P4, A4, E2) from follicle wall explants of four follicle size classes $(4-5.9 \mathrm{~mm}, 6-7.9 \mathrm{~mm}, 8-9.9 \mathrm{~mm}$ and F1) are shown in Fig. 5. InhA and P4 secretion (per $\mu \mathrm{g}$ DNA) showed the most dramatic changes, being substantially higher in the F1 than at all other size classes examined $(P<0 \cdot 001)$. InhA secretion was below the assay detection limit in $4-7.9 \mathrm{~mm}$ follicle cultures, low but detectable in $8-9 \cdot 9 \mathrm{~mm}$ follicles but $\sim 200$-fold higher in F1. Although P4 was detectable in all follicle cultures analysed, levels were not significantly $(P>0 \cdot 05)$ different 
a)

Whole follicle $\square$ Granulosa layer $\square$ Theca Layer

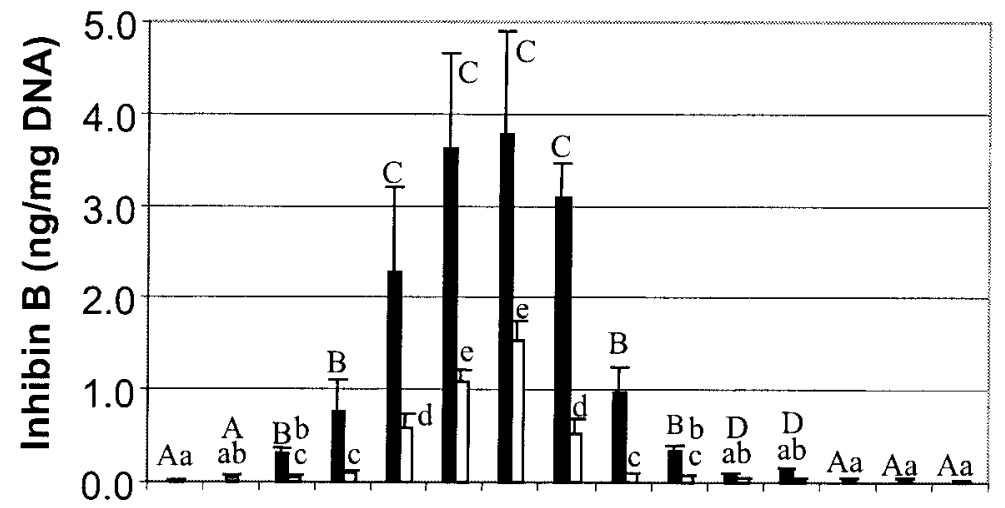

b)

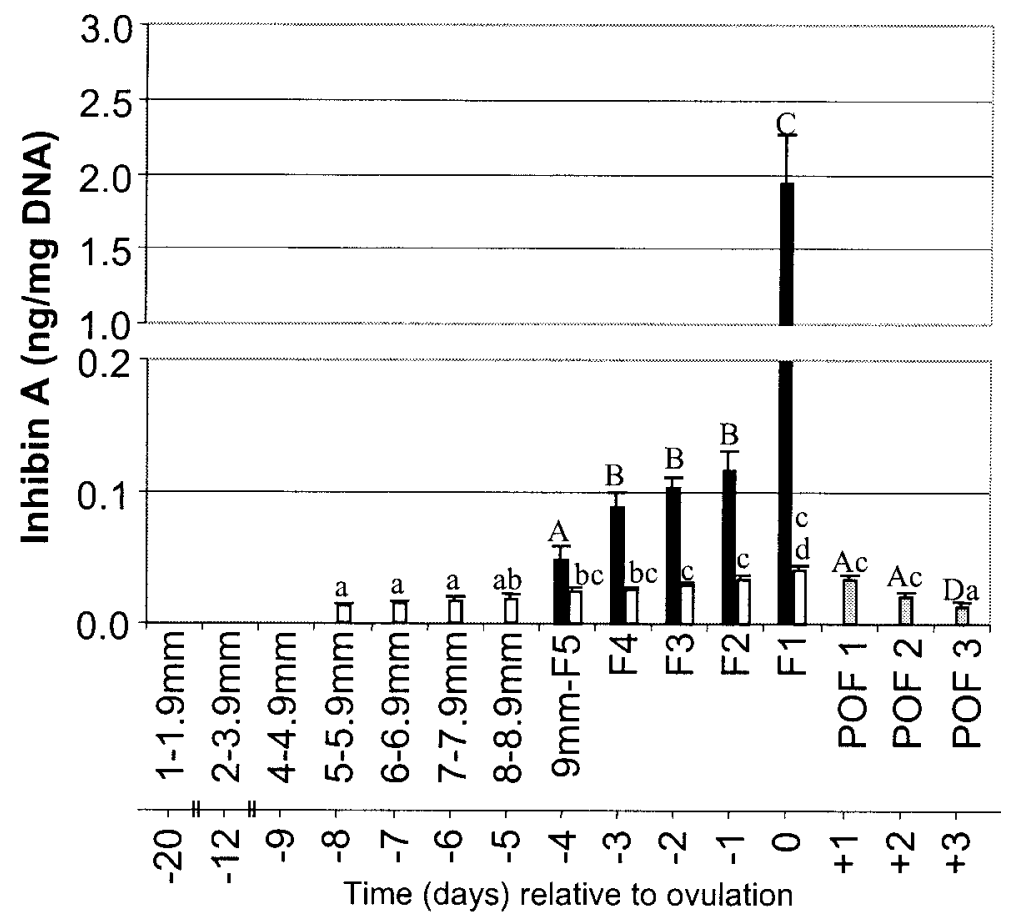

Figure 2 Concentrations (ng/mg DNA) of (a) inhB and (b) inhA in extracts of chicken ovarian follicles ranging in size from $1 \mathrm{~mm}$ to $\sim 40 \mathrm{~mm}$ (F1). With the exception of 1-3.9 $\mathrm{mm}$ and POFs, granulosa and thecal layers were separated and assayed individually. Fn represents the hierarchical follicle order with the largest follicle designated F1. POF $n$ represents POFs with POF 1 being the most recent. Values are means \pm S.E.M. $(n=11)$ and means without a common same-case letter are significantly $(P<0 \cdot 05)$ different (by ANOVA and Fisher's PLSD test). The detection limits of the inhB and inhA assays were equivalent to $24 \mathrm{pg} / \mathrm{mg}$ DNA and $4 \mathrm{pg} / \mathrm{mg}$ DNA respectively. The lower time-scale provides an estimate of the time taken for follicles of a given size category to reach the point of ovulation (based on the observations of Gilbert et al. 1983).

from 4 to $9.9 \mathrm{~mm}$ in diameter but were $\sim 140$-fold higher in F1. In contrast to inhA, secretion of inhB increased progressively from below the detection limit in $4-5.9 \mathrm{~mm}$ follicles to peak in $8-9.9 \mathrm{~mm}$ follicles before falling to below the assay detection limit in F1. FS secretion was detectable in all follicle cultures analysed; levels were not significantly $(P>0 \cdot 05)$ different from 4 to $9.9 \mathrm{~mm}$ in diameter but were significantly $(P<0 \cdot 05)$ reduced in $\mathrm{F} 1$. ActA secretion, in contrast to its binding protein FS, fell 2-fold $(P<0 \cdot 01)$ from $4-5.9$ to $8-9.9 \mathrm{~mm}$ before rising again $(3 \cdot 6$-fold; $P<0 \cdot 01)$ in F1. E2 secretion decreased progressively $(3 \cdot 3$-fold; $P<0 \cdot 001)$ during follicle 
a)

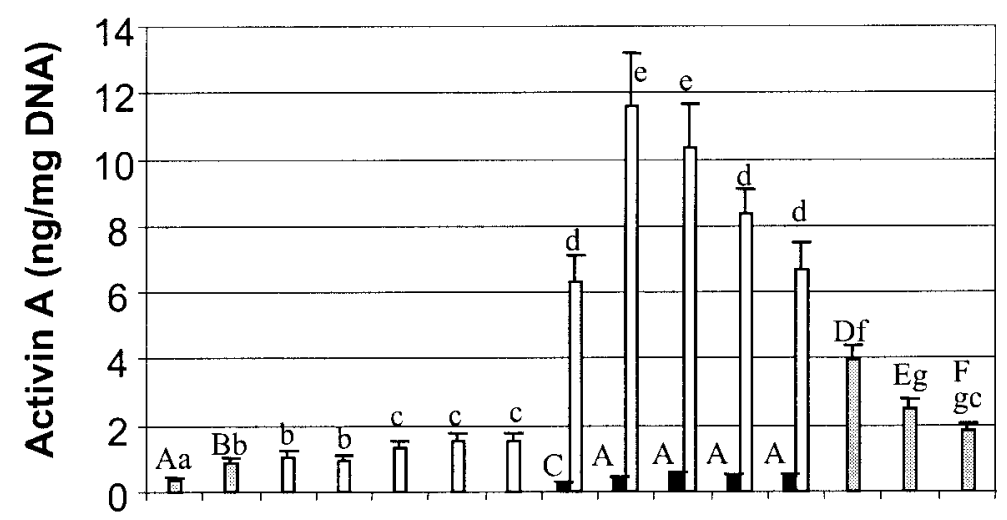

b)

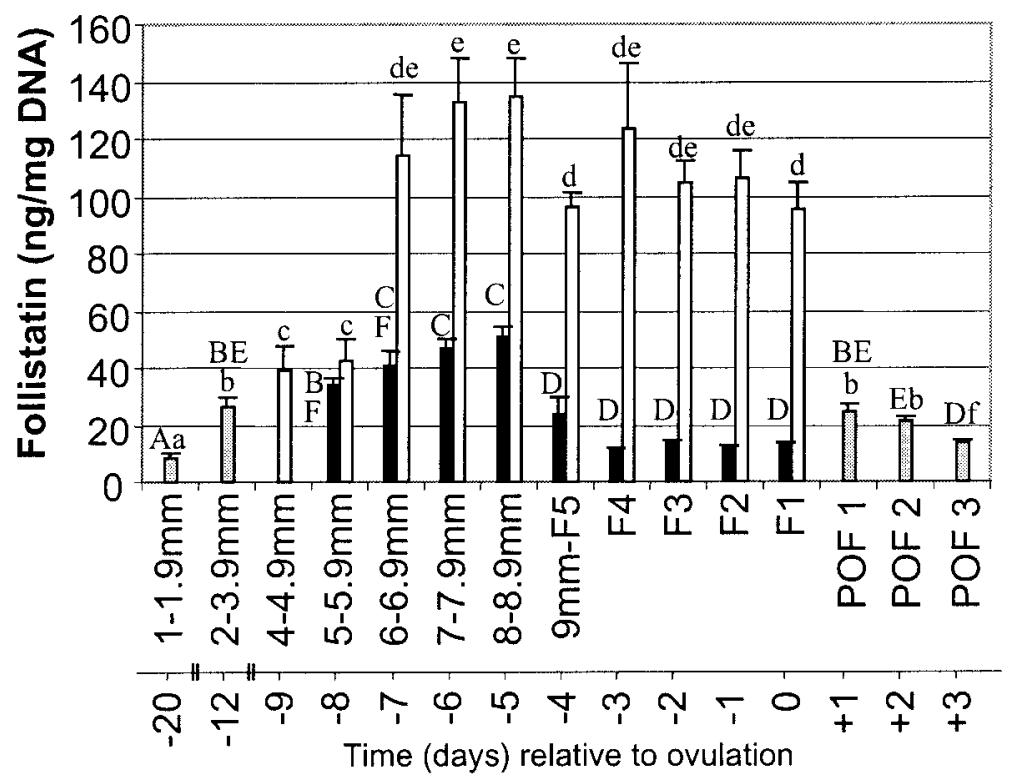

Figure 3 Concentrations (ng/mg DNA) of (a) actA and (b) FS in extracts of chicken ovarian follicles ranging in size from $1 \mathrm{~mm}$ to $\sim 40 \mathrm{~mm}$ (F1). With the exception of $1-3.9 \mathrm{~mm}$ and POFs, granulosa and thecal layers were separated and assayed individually. Fn represents the hierarchical follicle order with the largest follicle designated F1. POF $n$ represents POFs with POF 1 being the most recent. Values are means \pm S.E.M. $(n=11)$ and means without a common same-case letter are significantly $(P<0 \cdot 05)$ different (by ANOVA and Fisher's PLSD test). The detection limits of the actA and FS assays were equivalent to $80 \mathrm{pg} / \mathrm{mg}$ DNA and $1 \mathrm{ng} / \mathrm{mg}$ DNA respectively. The lower time-scale provides an estimate of the time taken for follicles of a given size category to reach the point of ovulation (based on the observations of Gilbert et al. 1983).

development with the sharpest decrease between 8-9.9 mm and F1. In contrast, A4 secretion did not vary significantly between the four follicle categories studied.

\section{Discussion}

The present study is the first to quantify inhB and FS proteins in the developing ovarian follicles of the domestic fowl. Moreover, we have confirmed and extended pre- vious findings on the expression of inhA and actA proteins in follicles of the preovulatory hierarchy (Lovell et al. 1998) through a comprehensive analysis of follicles from a much earlier, prehierarchical stage of development. The range of follicle size categories analysed here $(1 \mathrm{~mm}$ through $\mathrm{F} 1$ status to POF 3) corresponds to a developmental timespan of some 20 days (Gilbert et al. 1983, Perry et al. 1983).

The most striking finding of this study was the complete dissociation between follicular inhB and inhA expression. InhB content increased dramatically from $\sim 1 \mathrm{~mm}$, to 


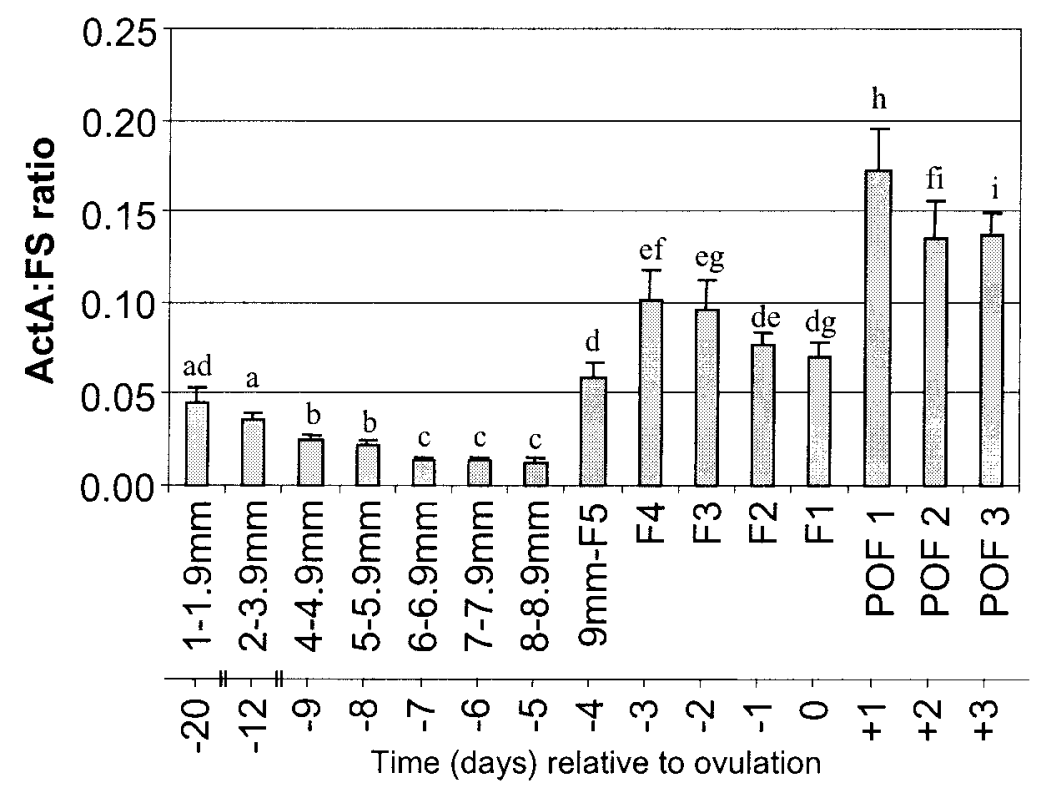

Figure 4 ActA:FS ratio calculated for combined $\mathrm{T}$ and $\mathrm{G}$ layers of chicken ovarian follicles ranging in size from $1 \mathrm{~mm}$ to $\sim 40 \mathrm{~mm}$ (F1). Fn represents the hierarchical follicle order with the largest follicle designated F1. POF $n$ represents POFs with POF 1 being the most recent. Values are means \pm S.E.M. $(n=11)$ and means without a common letter are significantly $(P<0 \cdot 05)$ different (by ANOVA and Fisher's PLSD test). The lower time-scale provides an estimate of the time taken for follicles of a given size category to reach the point of ovulation (based on the observations of Gilbert et al. 1983).

peak in 7-9 $\mathrm{mm}$ follicles before falling steeply as follicles entered the hierarchy and advanced towards F1. In complete contrast to inhB, and in agreement with our earlier finding (Lovell et al. 1998), inhA was undetectable in the $\mathrm{G}$ layer of follicles $<9 \mathrm{~mm}$ but increased $\sim 40$-fold from $9 \mathrm{~mm}$ to $\mathrm{F} 1$ with the sharpest increase during the F2 to F1 transition. Whilst comparable measurements of dimeric inhA and inhB protein contents of different follicle size classes have not yet been reported in mammals, a similar differential expression pattern may exist, since $G$ cells of small antral follicles predominantly express mRNA and/or protein for the $\beta \mathrm{B}$-subunit while large antral follicles (dominant, E2-active) express increasing amounts of $\beta A$ - and $\alpha$-subunit (Schwall et al. 1990, Roberts et al. 1993, Ireland \& Ireland 1994, Tisdall et al. 1994, Findlay et al. 2001). A follicle size-dependent change in $\beta \mathrm{A} / \beta \mathrm{B}-$ subunit mRNA expression pattern has also been demonstrated in avian G cells (Davis \& Johnson 1998) consistent with the present findings of differential production of inhA and inhB proteins.

Ovarian steroidogenesis is dependent on the stage of follicular development with both $\mathrm{T}$ and $\mathrm{G}$ cells contributing to follicular steroid output. G cells from prehierarchical 3-8 $\mathrm{mm}$ hen follicles are steroidogenically incompetent because they lack cytochrome P450 sidechain cleavage enzyme (P450 scc; Tilly et al. 1991b) and 3ß-hydroxysteroid dehydrogenase (in $<5 \mathrm{~mm}$; Davidson et al. 1979). Therefore, nearly all steroids secreted by hen follicles $<8 \mathrm{~mm}$ are derived from the surrounding $\mathrm{T}$ layers (interna and externa). Chicken FSH receptor mRNA is detectable in both $\mathrm{T}$ and $\mathrm{G}$ layers of follicles from $3 \mathrm{~mm}$ through to F1 (You et al. 1996). While chicken LH receptor mRNA was detectable in $\mathrm{T}$ tissue from $3 \mathrm{~mm}$ onwards it was not expressed by G cells until 9-12 mm follicles with levels increasing significantly in F3-F1 preovulatory follicles (Johnson et al. 1996). G cell expression of FSH receptor mRNA peaks in 6-8 mm follicles (You et al. 1996) and treatment of 6-8 mm follicle $G$ cells with FSH can render them responsive to LH (Tilly et al. 1991a). While $G$ cells of small follicles may be steroidogenically inactive, this study has shown that they are clearly capable of producing significant quantities of inhB and FS. FSH and $\mathrm{E} 2$ have been shown to affect inhibin/activin $\beta \mathrm{B}$ subunit mRNA expression in cultured $G$ cells from small (F4/F5) preovulatory follicles following short-term (4 h) incubation (Davis et al. 2000, 2001). Our finding that inhB content and secretion is greatly raised in prehierarchical follicles accords well with the report of Hecht et al. (2000) showing that expression of inh/act $\beta$ B-subunit mRNA was maximal in $6-8 \mathrm{~mm}$ follicles. It is thus tempting to speculate that the dramatic increase in production of inhB in 6-9 $\mathrm{mm}$ follicles is involved in $\mathrm{G}$ 

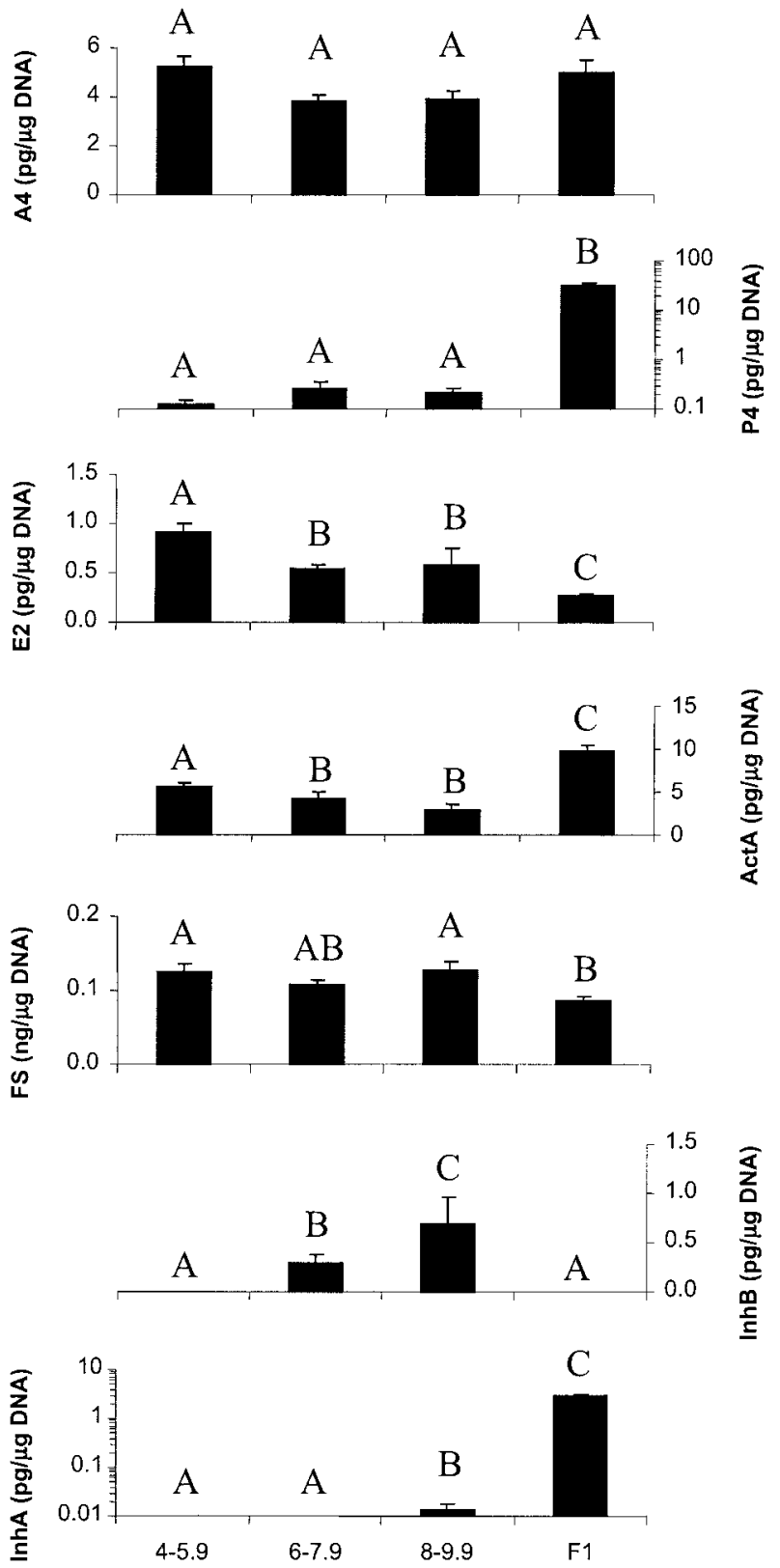

Figure 5 Comparison of in vitro hormone secretion from hen follicle wall explants $(4-5.9 \mathrm{~mm}, 6-7.9 \mathrm{~mm}, 8-9.9 \mathrm{~mm}$ and $\mathrm{F} 1$ follicles) during a 24-h culture period. Values are means \pm S.E.M. $(n=4-9)$ and have been normalized to tissue DNA content. Results of ANOVA are shown and bars with different letters are significantly different $(P<0 \cdot 05)$. Note that $\mathrm{P} 4$ and inhA values are plotted on a log scale.

cell acquisition of steroidogenic competence and/or increased gonadotrophin responsiveness, prerequisites for recruitment to the preovulatory hierarchy.

It seems likely that the intrafollicular balance between inhibin, activin and its binding protein FS is important in determining follicular response to these proteins (Findlay et al. 2001, Knight \& Glister 2001). However, while the present study has clearly shown that such changes occur, it is not possible to assess whether these merely reflect, rather than contribute to, the process(es) which drive follicles through specific developmental checkpoints during folliculogenesis. Nonetheless, the observation of a concomitant rise in the inhB and FS content of both $\mathrm{T}$ and $\mathrm{G}$ layers of 6-9 $\mathrm{mm}$ follicles, unaccompanied by a rise in the FS ligand actA, lends support to the notion of a marked though transient increase in 'inhibin tone' (and corresponding decrease in 'activin tone') in follicles approaching the point of entry into the preovulatory hierarchy. It is also possible that the dramatic though transient inhB rise in 6-9 mm follicles reflects not transition into, but away from, entry into the preovulatory hierarchy and towards follicle deletion; after all, only one follicle is recruited to the preovulatory hierarchy during a typical ovulatory cycle. In addition, since we are not yet able to quantify activin $\mathrm{B}$ we cannot rule out the possibility that levels of this activin isoform are raised in prehierarchical follicles concomitantly with raised inhB (this study) and $\beta \mathrm{B}$-subunit mRNA (Hecht et al. 2000).

Studies in mammals indicate that activin can promote proliferation, inhA and B production (Lanuza et al. 1999, Boudjemaa et al. 2000, Findlay et al. 2001) and FSH receptor expression by undifferentiated rat $G$ cells (Hasegawa et al. 1988, Xiao et al. 1992) and, in turn, promote FSH-induced stimulation of $\mathrm{LH}$ receptor expression and upregulation of steroidogenesis (Hillier et al. 1994). From the present observations, 'activin tone' appears to decrease progressively as small follicles grow from $1-2 \mathrm{~mm}$ to $\sim 9 \mathrm{~mm}$, the approximate point of recruitment into the preovulatory hierarchy. The apparently high 'activin tone' of small hen follicles (1-2 mm) might explain how such a follicle acquires FSH responsiveness and subsequently progresses to an LH-responsive stage of development. Given the ability of FS to bind and neutralize activin, the proposed action of activin to promote FSH receptor expression in small follicles would operate most successfully in the absence of FS. Similarly, since inhibins antagonize most of the actions of activin, low levels of inhibin should favour activin action. In this study, follicular actA contents were relatively uniform in follicles ranging from $1 \mathrm{~mm}$ to $9 \mathrm{~mm}$ while FS contents increased progressively from $1 \mathrm{~mm}$ to $7 \mathrm{~mm}$ suggesting a gradually attenuation of 'activin tone' (see Fig. 4). The subsequent increase in inhB levels between $5 \mathrm{~mm}$ and $8 \mathrm{~mm}$ would further diminish 'activin tone' relative to 'inhibin tone'.

Recruitment to the preovulatory hierarchy was associated with a marked rise in actA ( $\sim 6$-fold rise; $9 \mathrm{~mm}$ to $\mathrm{F} 4)$, predominantly in the $\mathrm{T}$ layer but also evident in the $\mathrm{G}$ layer. This was accompanied by a $\sim 4$-fold decline in the FS content of the G layer. These conditions would enhance the interaction of $\mathrm{T}$-derived actA with receptors 


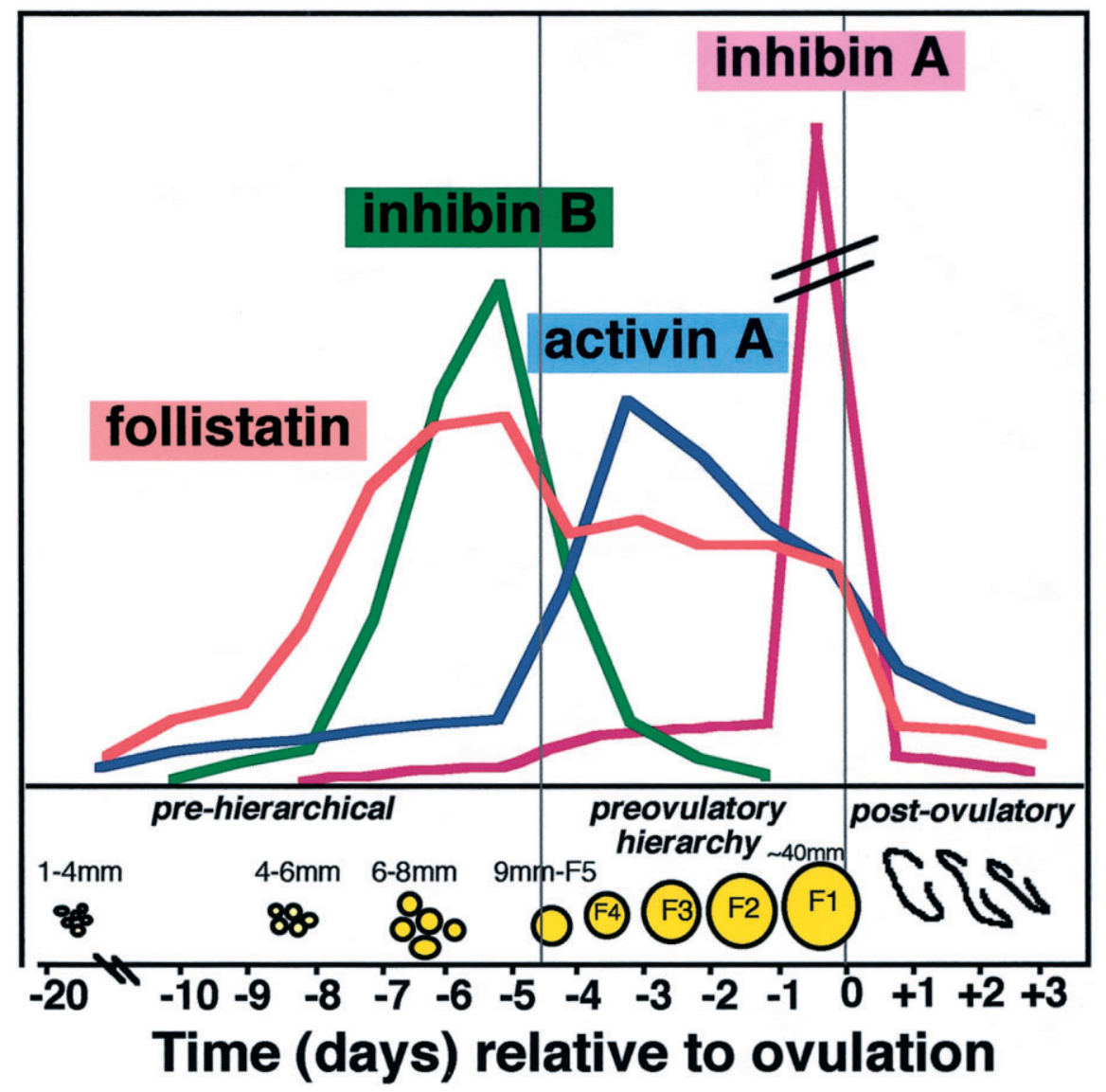

Figure 6 This shows the developmental profiles of intrafollicular inhA and B, actA and FS during folliculogenesis in the laying hen.

on $\mathrm{G}$ cells. Moreover, the inhB content of both $\mathrm{G}$ and $\mathrm{T}$ fell substantially between $9 \mathrm{~mm}$ and $\mathrm{F} 4$. We propose, therefore, that these apparent shifts in the balance between 'inhibin tone' and 'activin tone' are of physiological significance. In vitro studies with mammalian cells have shown that activin can promote $\mathrm{G}$ cell proliferation ( $\mathrm{Li}$ et al. 1995, Miro \& Hillier 1996) and upregulate P450 scc (Miro et al. 1995), basal and gonadotrophin-stimulated P450 aromatase (P450 arom) activity and E2 secretion (Miro et al. 1991, Shukovski et al. 1991, 1993, Hillier \& Miro 1993), effects which are counteracted by FS treatment. It has been shown that FSH-stimulated growth of mouse primary follicles $(100-120 \mu \mathrm{m})$ is halted by co-incubation with secondary follicles $(300-350 \mu \mathrm{m})$ and that this response is mediated by activin (Mizunuma et al. 1999). Is the rise in T 'activin tone' in hen preovulatory follicles part of a mechanism for regulating follicle growth and entry into the hierarchy? Is this associated with known alterations in follicular steroidogenic activity, gonadotrophin responsiveness or cell proliferation in the chicken ovary?
According to Etches \& Duke (1984), the E2 content of hen $\mathrm{T}$ tissue is much higher than that of $\mathrm{G}$ tissue; moreover, oestrogen levels (Etches \& Duke 1984) and P450 arom activity (Armstrong 1984, Kato et al. 1995) are greater in F3/F4 than in F1 T tissue. Interestingly, this pattern mirrors the actA profile observed in the present study, raising the suggestion that a high 'activin tone' promotes $\mathrm{T} \mathrm{P} 450$ arom activity in the hen, possibly through enhancement of gonadotrophin responsiveness. The finding that $\mathrm{LH}$ increased oestrogen production by cultured T cells from F3 follicles but not from F1 follicles (Marrone $\&$ Hertelendy 1985) lends some support to this possibility.

As selected follicles moved up the preovulatory hierarchy, and particularly during the final F2-F1 transition when $\mathrm{P} 4$ production increased dramatically, their relative 'activin tone' decreased again as reflected by a large rise in inhA, a modest fall in actA and a relatively constant FS level. The finding that the F1 G layer is by far the richest source of inhA in the chicken ovary concurs with our previous finding (Lovell et al. 1998) and is consistent with 
$\alpha$ - and $\beta A$-subunit mRNA expression studies (Chen \& Johnson 1996). Various factors have been shown to modulate secretion of inhA and $\mathrm{P} 4$ from cultured chicken F1-F3 G cells, including FSH, LH, IGF-I and actA (Lovell et al. 2002a,b). Cyclic variation in plasma inhA level has also been noted during the hen ovulatory cycle with a modest peak around the time of the preovulatory rise in LH and P4 (Lovell et al. 2000b); it is assumed that this peak in plasma inhA is mostly derived from the F1 follicle. Using the current inhB ELISA we have been unable to detect inhB in the peripheral circulation of laying hens, although levels were detectable in plasma of adult cockerels (Lovell et al. 2000a). Whether the dramatic difference in $\mathrm{P} 4$ secretion between $6-9 \mathrm{~mm}$ follicles and the preovulatory F1 follicle is linked to the divergent pattern of expression of the two isoforms of inhibin in $G$ cells or to actA in T cells is unknown.

In conclusion, on the basis of the sequence of changes observed in follicular contents of inhA, inhB, actA and FS (see Fig. 6), we suggest that relative 'activin tone' decreases progressively from 1-2 $\mathrm{mm}$ (the smallest follicle category analysed) to a nadir in $7-9 \mathrm{~mm}$ follicles on the threshold of entry into the preovulatory hierarchy, increases again as the selected follicle enters the preovulatory hierarchy (F5/F4) before falling again as the follicle approaches the F1 position. Finally, after ovulation the relative 'activin tone' of the POF increases once again as reflected by a pronounced fall in inhA and FS accompanied by only a modest fall in actA content. The observation that sequential shifts in the balance between 'activin tone' and 'inhibin tone' occur over a time-scale of about 20 days of follicle development, together with the finding of a striking divergence in the pattern of inhA and inhB expression, imply important functional role(s) of the inhibin-activin system in avian folliculogenesis that warrants further study.

\section{Acknowledgements}

We thank Dr A F Parlow (NHPP) for providing recombinant human follistatin, Dr M Rose (NIBSC) for recombinant human actA and inhA and Mr S A Feist for skilled technical assistance. This work was supported by the BBSRC (grants 45/S11514 and 45/S17120).

\section{References}

Armstrong DG 1984 Ovarian aromatase activity in the domestic fowl (Gallus domesticus). Journal of Endocrinology 100 81-86.

Boudjemaa ML, Rouillier P, Bhatia B, Silva JM. Guilbault LA \& Price CA 2000 Effect of FSH and cell localization on dimeric inhibin-A secretion from bovine granulosa cells in culture. Journal of Endocrinology 165 207-215.

Chen CC \& Johnson PA 1996 Expression of inhibin $\alpha$ and inhibin/ activin $\beta_{\mathrm{A}}$ subunits in the granulosa layer of the large preovulatory follicles of the hen. Biology of Reproduction 55 450-454.
Davidson MF, Gilbert AB \& Wells JW 1979 Activity of ovarian $\Delta 5-3 \beta$ hydroxysteroid dehydrogenase in the domestic fowl (Gallus domesticus) with respect to age. Journal of Reproduction and Fertility $\mathbf{5 7}$ 61-64.

Davis AJ \& Johnson PA 1998 Expression pattern of messenger ribonucleic acid for follistatin and the inhibin/activin subunits during follicular and testicular development in Gallus domesticus. Biology of Reproduction 59 271-277.

Davis AJ, Brooks CF \& Johnson PA 2000 Estradiol regulation of follistatin and inhibin $\alpha$ - and $\beta_{\mathrm{B}}$-subunit mRNA in avian granulosa cells. General and Comparative Endocrinology 119 308-316.

Davis AJ, Brooks CF \& Johnson PA 2001 Follicle-stimulating hormone regulation of inhibin $\alpha$ - and $\beta_{\mathrm{B}}$-subunit and follistatin messenger ribonucleic acid in cultured avian granulosa cells. Biology of Reproduction 64 100-106.

Etches RJ \& Duke CE 1984 Progesterone, androstenedione and oestradiol content of theca and granulosa tissue of the four largest ovarian follicles during the ovulatory cycle of the hen (Gallus domesticus). Journal of Endocrinology 103 71-76.

Evans LW 1997 The Development of Immunoassays for Follistatin and Activin and their Clinical Applications. PhD Thesis: Oxford Brookes University.

Findlay JK, Drummond AE, Dyson M, Baillie AJ, Robertson DM \& Ethier JF 2001 Production and actions of inhibin and activin during folliculogenesis in the rat. Molecular and Cellular Endocrinology $\mathbf{1 8 0}$ 139-144.

Gilbert AB, Evans AJ, Perry MM \& Davidson MH 1977 A method for separating the granulosa cells, the basal lamina and the theca of the preovulatory ovarian follicle of the domestic fowl (Gallus domesticus). Journal of Reproduction and Fertility 50 179-181.

Gilbert AB, Perry MM, Waddington D \& Hardie MA 1983 Role of atresia in establishing the follicular hierarchy in the ovary of the domestic hen (Gallus domesticus). Journal of Reproduction and Fertility $69221-227$.

Glister C, Tannetta DS, Groome NP \& Knight PG 2001 Interactions between follicle-stimulating hormone and growth factors in modulating secretion of steroid and inhibin-related peptides by nonluteinized bovine granulosa cells. Biology of Reproduction $\mathbf{6 5}$ $1020-1028$

Groome NP, Illingworth PJ, O'Brien M, Pai R, Rodger FE, Mather JP \& McNeilly AS 1996 Measurement of dimeric inhibin B throughout the human menstrual cycle. Journal of Clinical Endocrinology and Metabolism 81 1401-1405.

Hasegawa Y, Miyamoto K, Abe Y, Nakamura T, Sugino H, Eto Y, Shibai H \& Igarashi M 1988 Induction of follicle stimulating hormone receptor by erythroid differentiation factor on rat granulosa cell. Biochemical and Biophysical Research Communications $156668-674$

Hecht DJ, Davis AJ, Brooks CF \& Johnson PA 2000 Molecular cloning and expression analysis of the complementary deoxyribonucleic acid for chicken inhibin/activin $\beta_{\mathrm{B}}$ subunit. Biology of Reproduction 62 1128-1134.

Hillier SG \& Miro F 1993 Local regulation of primate granulosa cell aromatase activity. Journal of Steroid Biochemistry and Molecular Biology 44 435-439.

Hillier SG, Whitelaw PF \& Smyth CD 1994 Follicular oestrogen synthesis: the 'two-cell, two-gonadotrophin' model revisited. Molecular and Cellular Endocrinology 100 51-54.

Ireland JL \& Ireland JJ 1994 Changes in expression of inhibin/activin alpha, beta $\mathrm{A}$ and beta $\mathrm{B}$ subunit messenger ribonucleic acid following increases in size and during different stages of differentiation or atresia of non-ovulatory follicles in cows. Biology of Reproduction 50 492-501.

Johnson AL, Bridgham JT \& Wagner B 1996 Characterization of a chicken luteinizing hormone receptor (cLH-R) complementary deoxyribonucleic acid, and expression of cLH-R messenger ribonucleic acid in the ovary. Biology of Reproduction 55 304-309. 
Kato M, Shimada K, Saito N, Noda K \& Ohta M 1995 Expression of P450 17 $\alpha$-hydroxylase and P450 aromatase genes in isolated granulosa, theca interna, and theca externa layers of chicken ovarian follicles during follicular growth. Biology of Reproduction 52 405-410.

Knight PG \& Glister C 2001 Potential local regulatory functions of inhibins, activins and follistatin in the ovary. Reproduction 121 503-512.

Knight PG, Muttukrishna S \& Groome NP 1996 Development and application of a two-site enzyme immunoassay for the determination of 'total' activin-A concentrations in serum and follicular fluid. Journal of Endocrinology 148 267-279.

Labarca C \& Paigen K 1980 A simple, rapid, and sensitive DNA assay procedure. Analytical Biochemistry 102 344-352.

Lanuza GM, Groome NP, Baranao JL \& Campo S 1999 Dimeric inhibin $\mathrm{A}$ and $\mathrm{B}$ production are differentially regulated by hormones and local factors in rat granulosa cells. Endocrinology 140 2549-2554.

Li R, Phillips DM \& Mather JP 1995 Activin promotes ovarian follicle development in vitro. Endocrinology 125 2134-2140.

Lovell TM, Gladwell RT, Cunningham FJ, Groome NP \& Knight PG 1998 Differential changes in inhibin A, activin A, and total $\alpha$-subunit levels in granulosa and thecal layers of developing preovulatory follicles in the chicken. Endocrinology 139 1164-1171.

Lovell TM, Knight PG, Groome NP \& Gladwell RT 2000a

Measurement of dimeric inhibins and effects of active immunization against inhibin $\alpha$-subunit on plasma hormones and testis morphology in the developing cockerel. Biology of Reproduction 63 213-221.

Lovell TM, Vanmontfort D, Bruggeman V, Decuypere E, Groome NP, Knight PG \& Gladwell RT 2000b Circulating concentrations of inhibin-related proteins during the ovulatory cycle of the domestic fowl (Gallus domesticus) and after induced cessation of egg laying. Journal of Reproduction and Fertility 119 232-238.

Lovell TM, Knight PG, Groome NP \& Gladwell RT 2001 Changes in plasma inhibin A levels during sexual maturation in the female chicken and the effects of active immunization against inhibin $\alpha$-subunit on reproductive hormone profiles and ovarian function. Biology of Reproduction 64 188-196.

Lovell TM, Gladwell RT, Groome NP \& Knight PG 2002a Modulatory effects of gonadotrophins and insulin-like growth factor on the secretion of inhibin A and progesterone by granulosa cells from chicken preovulatory (F1-F3) follicles. Reproduction $\mathbf{1 2 3}$ 291-300.

Lovell TM, Gladwell RT, Groome NP \& Knight PG $2002 b$ Activin exerts differential effects on basal and gonadotrophin-induced secretion of inhibin A and progesterone by granulosa cells from chicken preovulatory (F1-F3) follicles. Reproduction 124 649-657.

Marrone BL \& Hertelendy F 1985 Decreased androstenedione production with increased follicular maturation in theca cells from the domestic hen (Gallus domesticus). Journal of Reproduction and Fertility 74 543-550.

Miro F \& Hillier SG 1996 Modulation of granulosa cell deoxyribonucleic acid synthesis and differentiation by activin. Endocrinology 137 464-468.

Miro F, Smyth CD \& Hillier SG 1991 Development-related effects of recombinant activin on steroid synthesis in rat granulosa cells. Endocrinology 129 3388-3394.

Miro F, Smyth CD, Whitelaw PF, Milne M \& Hillier SG 1995 Regulation of $3 \beta$-hydroxysteroid $\Delta 5 / \Delta 4$-isomerase and cholesterol side-chain cleavage cytochrome $\mathrm{P} 450$ by activin in rat granulosa cells. Endocrinology 136 3247-3252.

Mizunuma H, Liu X, Andoh K, Abe Y, Kobayashi J, Yamada K, Yokota H, Ibuki Y \& Hasegawa Y 1999 Activin from secondary follicles causes small preantral follicles to remain dormant at the resting stage. Endocrinology $14037-42$.

Muttukrishna S, Fowler PA, Groome NP, Mitchell GG, Robertson WR \& Knight PG 1994 Serum concentrations of dimeric inhibin during the spontaneous human menstrual cycle and after treatment with exogenous gonadotrophin. Human Reproduction 9 1634-1642.

Perry MM, Waddington D, Gilbert AB \& Hardie MA 1983 Growth rates of the small yolky follicles in the ovary of the domestic fowl. IRCS Medical Science 11 979-980.

Roberts VJ, Barth S, el-Roeiy A \& Yen SS 1993 Expression of inhibin/activin subunits and follistatin messenger ribonucleic acids and proteins in ovarian follicles and the corpus luteum during the human menstrual cycle. Journal of Clinical Endocrinology and Metabolism 77 1402-1410.

Sauer MJ, Foulkes JA, Worsfold A \& Morris BA 1986 Use of progesterone 11-glucuronide-alkaline phosphatase conjugate in a sensitive microtitre-plate enzymeimmunoassay of progesterone in milk and its application to pregnancy testing in dairy cattle. Journal of Reproduction and Fertility 76 375-391.

Schwall RH, Mason AJ, Wilcox JN, Bassett SG \& Zeleznik AJ 1990 Localization of inhibin/activin subunit mRNAs within the primate ovary. Molecular Endocrinology 4 75-79.

Shukovski L, Findlay JK \& Robertson DM 1991 The effect of follicle-stimulating hormone-suppressing protein or follistatin on luteinizing bovine granulosa cells in vitro and its antagonistic effect on the action of activin. Endocrinology 129 3395-3402.

Shukovski L, Dyson M \& Findlay JK 1993 The effect of follistatin, activin and inhibin on steroidogenesis by bovine thecal cells. Molecular and Cellular Endocrinology 97 19-27.

Tilly JL 1996 Apoptosis and ovarian functions. Reviews of Reproduction 1 162-172.

Tilly JL, Kowalski KI \& Johnson AL 1991a Stage of ovarian follicular development associated with the initiation of steroidogenic competence in avian granulosa cells. Biology of Reproduction $\mathbf{4 4}$ 305-314.

Tilly JL, Kowalski KI \& Johnson AL $1991 b$ Cytochrome P450 side-chain cleavage (P450 scc) in the hen ovary. II. P450 scc messenger RNA, immunoreactive protein, and enzyme activity in developing granulosa cells. Biology of Reproduction 45 967-974.

Tilly JL, Kowalski KI, Johnson AL \& Hsueh AJW 1991c Involvement of apoptosis in ovarian follicular atresia and postovulatory regression. Endocrinology 129 2799-2801.

Tisdall DJ, Hudson N, Smith P \& McNatty KP 1994 Localization of ovine follistatin and alpha and $\beta A$ inhibin mRNA in the sheep ovary during the oestrous cycle. Journal of Molecular Endocrinology 12 181-193.

Wrathall JHM \& Knight PG 1995 Effects of inhibin-related peptides and oestradiol on androstenedione and progesterone secretion by bovine theca cells in vitro. Journal of Endocrinology 145 491-500.

Xiao S, Robertson DM \& Findlay JK 1992 Effects of activin and follicle-stimulating hormone (FSH)-suppressing protein/follistatin on FSH receptors and differentiation of cultured rat granulosa cells. Endocrinology 131 1009-1016.

You S, Bridgham JT, Foster DN \& Johnson AL 1996 Characterization of the chicken follicle-stimulating hormone receptor (cFSH-R) complementary deoxyribonucleic acid, and expression of cFSH-R messenger ribonucleic acid in the ovary. Biology of Reproduction $\mathbf{5 5}$ $1055-1062$.

Received in final form 20 January 2003

Accepted 23 January 2003 